\title{
Evaluasi Kinerja Aset Fasilitas Rekreasi di Teras Cikapundung Kota Bandung
}

\author{
Karina Aurora Nadea \\ Program Studi Manajemen Aset Politeknik Negeri Bandung \\ Coresponding Author Email : karina.aurora.mas17@polban.ac.id
}

\begin{abstract}
One of the city parks designed as a recreation area is Teras Cikapundung. Teras Cikapundung has an area of 5,128 $\mathrm{m}^{2}$ and located in the Siliwangi area of Bandung City. Based on the results of preliminary observations have found several indications of problems with existing facilities in the Teras Cikapundung recreation area, namely non-operational children's rides, unavailability of parking spaces for bicycles, the stairs are not equipped with handrails, some of park chairs, picnic tables, and garden lights can't be used because in the damage condition, and there is only two kind of signage: direction and information. The purpose of this case study research is to determine the performance of facility assets based Recreational Facility Audit Tool and provide solutions or recommendations for problems in recreational facilities in Teras Cikapundung. The theory for this research based on 'The Recreational Facility Audit Tool' from Macfarlane et al (2013) includes availability of sport facilities, accessibility, and availability of supportive amenities. The research method is descriptive method with quantitative research approaches. The data collection techniques were observation, interview, and documentation study. The analysis techniques is using descriptive analysis techniques. Therefore, the recommended problem solving recommendation is the renovation of recreational facilities assets in Teras Cikapundung Bandung City.
\end{abstract}

Keywords: Asset Performance Evaluation, City Park, Recreational Facilities

\begin{abstract}
ABSTRAK
Salah satu taman kota yang dirancang sebagai tempat rekreasi taman kota adalah Teras Cikapundung. Teras Cikapundung memiliki luas sebesar $5.128 \mathrm{~m}^{2}$ dan berlokasi di daerah Siliwangi Kota Bandung. Berdasarkan hasil observasi pendahuluan ditemukan beberapa indikasi masalah pada fasilitas yang ada pada kawasan rekreasi Teras Cikapundung yaitu permainan anak yang tidak beroperasi, tidak tersedianya tempat parkir untuk sepeda, tangga yang disediakan tidak dilengkapi oleh pegangan, selain itu beberapa fasilitas kursi taman, meja piknik, dan lampu taman tidak dapat digunakan karena dalam kondisi rusak, serta hanya tersedia 2 jenis rambu yaitu rambu petunjuk arah dan informasi. Tujuan penelitian studi kasus ini untuk mengetahui kinerja aset fasilitas berdasarkan Recreational Facility Audit Tool dan memberikan solusi atau rekomendasi atas permasalahan yang terdapat pada fasilitas rekreasi di Teras Cikapundung. Teori yang digunakan pada penelitian ini adalah 'The Recreational Facility Audit Tool' dari Macfarlane et al (2013) meliputi availability of sport facilities, accessibility, dan availability of supportive amenities. Metode penelitian yang digunakan adalah metode deskriptif dengan pendekatan penelitian kuantitatif. Teknik pengumpulan data yang digunakan yaitu observasi, wawancara, dan studi dokumentasi. Teknik analisis yang digunakan adalah teknik analisis deskriptif. Rekomendasi pemecahan masalah yang disarankan dalam penelitian ini adalah renovasi aset fasilitas rekreasi di Teras Cikapundung Kota Bandung.
\end{abstract}

Kata kunci: Evaluasi; Kinerja Aset, Fasilitas Rekreasi, Taman Kota 


\section{PENDAHULUAN}

Ruang Terbuka Hijau (RTH) merupakan bagian dari penataan ruang kota yang memiliki fungsi untuk memberikan keseimbangan antara kualitas lingkungan dengan kemajuan sebuah kota. Ruang terbuka hijau telah ditujukkan bagi kesehatan masyarakat, kesejahteraan pribadi dan penyediaan layanan ekosistem perkotaan serta pemeliharaan keanekaragaman hayati (Ives et al, 2014). Ruang terbuka hijau adalah lahan yang mengandung unsur dan struktur alami dalam menjalani proses ekologis (Joga dan Ismaun, 2011). Menurut Samsudi (2010) fungsi ruang terbuka hijau terbagi menjadi fungsi ekologis, fungsi sosial budaya, fungsi arsitektural, dan fungsi ekonomi. RTH berperan penting dalam struktur pembentuk lingkungan kota karena memiliki fungsi utama sebagai penunjang ekologis kota yang dapat meningkatkan nilai kualitas lingkungan dan budaya suatu kawasan. Berdasarkan Peraturan Menteri Pekerjaan Umum Nomor: 05/PRT/M/2008 tentang Pedoman Penyediaan dan Pemanfaatan Ruang Terbuka Hijau di Kawasan Perkotaan disebutkan proporsi RTH pada wilayah perkotaan adalah sebesar minimal $30 \%$ yang terdiri dari 20\% RTH publik dan 10\% terdiri dari RTH privat. Salah satu jenis RTH di perkotaan adalah taman kota.

Menurut Irwan (2008) taman kota adalah taman yang ditujukan untuk melayani penduduk satu kota atau bagian wilayah kota. Taman kota memiliki berbagai fungsi yang berakitan dengan fungsi hidrologis, ekologi, kesehatan, estetika, sosial, edukasi, dan rekreasi (Atmojo, 2007). Salah satu taman kota di Kota Bandung adalah Taman Teras Cikapundung yang memiliki luas sebesar $5.128 \mathrm{~m}^{2}$. Teras Cikapundung dikelola oleh Balai Besar Wilayah Sungai Citarum di bawah Kementrian Pekerjaan Umum dan Perumahan Rakyat yang bertujuan sebagai upaya penataan di sepanjang Kawasan Sempadan Sungai Cikapundung. Terdapat banyak fasilitas yang disuguhkan seperti atraksi air mancur, jembatan merah yang menjadi tempat favorit untuk berfoto, amfiteater sebagai ruang publik yang dapat menampung hingga 1000 orang, dan kolam kura-kura.

Berdasarkan pengamatan pendahuluan, ditemukan beberapa masalah di Teras Cikapundung Kota Bandung. Teras Cikapundung menyediakan fasilitas sarana rekreasi aktif dan pasif. Fasilitas aktif tersebut berupa rafting dengan menggunakan perahu karet untuk menyusuri sungai Cikapundung dengan jarak 1,2 km - $2 \mathrm{~km}$, fasilitas tersebut belum dilengkapi oleh peralatan lengkap untuk olahraga rafting. Selain itu terdapat fasilitas rekreasi bermain anak-anak, namun mainan tersebut tidak terawat dan dibiarkan tidak beroperasi. Berikut ini kondisi fasilitas rekreasi bermain anak dapat dilihat pada gambar 1. 


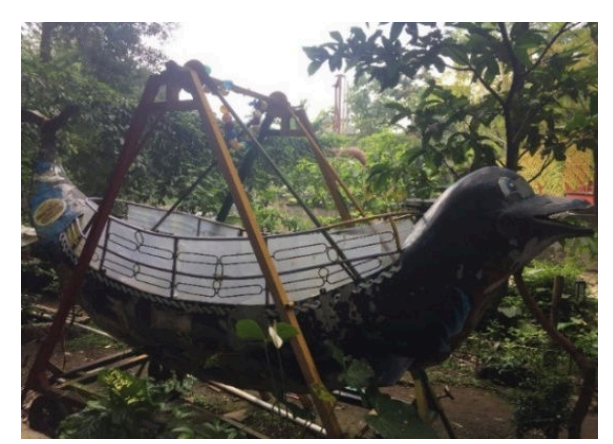

Gambar 1. Kondisi Fasilitas Bermain Anak Sumber : Penyusun, 2021

Selain itu terdapat permasalahan pada aksesibilitas. Aksesibilitas didefinisikan sebagai "relative mudahnya" suatu lokasi untuk dijangkau dari tempat-tempat lainnya dan seberapa terbuka situs tersebut bagi public (Siljeg et al, 2018). Permasalahan aksesibilitas yaitu penyediaan lahan parkir dan tangga. Teras Cikapundung tidak menyediakan tempat parkir untuk pengunjung yang datang menggunakan sepeda, selain itu tidak ada pembatas antara tempat parkir mobil dan motor. Pada Teras Cikapundung terdapat tempat makan yang terletak di daerah perbukitan sehingga untuk mengakses lokasi tersebut perlu menggunakan tangga, namun tangga yang disediakan di Teras Cikapundung dimensi pijakan dan tanjakannya tidak sama, ditumbuhi oleh lumut sehingga licin, dan tidak dilengkapi oleh pegangan. Kondisi tersebut dapat dilihat pada gambar 2.

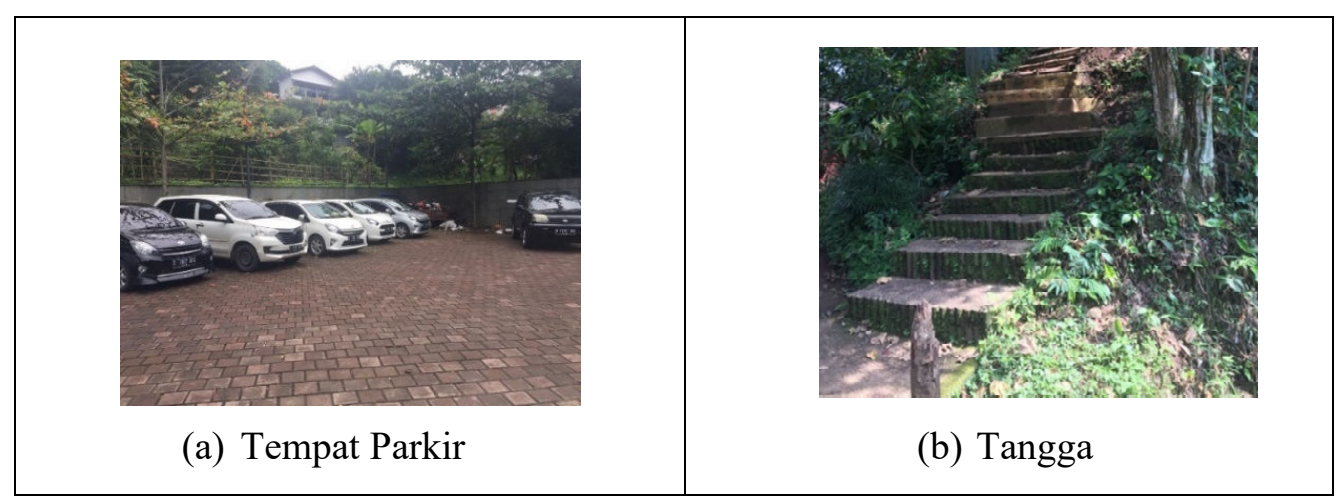

Gambar 2. Kondisi Tempat Parkir dan Tangga

Sumber : Penyusun, 2021

Salah satu yang harus disediakan di tempat rekreasi adalah fasilitas pendukung bagi wisatawan yang berkunjung pada destinasi wisata. Menurut Peraturan Menteri Pariwisata Nomor 5 Tahun 2019, amenities adalah fasilitas penunjang yang dapat memberikan kemudahan ketika wisatawan sedang berwisata. Di Teras Cikapundung terdapat banyak fasilitas yang rusak seperti kursi taman, meja piknik, dan lampu taman yang pecah lampu. Fasilitas toilet yang disediakan pun kotor, tidak dibedakan berdasarkan gender, dan tidak 
dilengkapi oleh peralatan yang lengkap. Selain itu belum disediakan papan petunjuk yang menandakan atau mengarahkan pengunjung mengenai masing-masing zona, hanya dibatasi oleh jembatan merah yang menjadi pembatas antara zona buatan dan zona natural. Kondisi fasilitas tersebut dapat dilihat pada gambar 3 berikut ini.

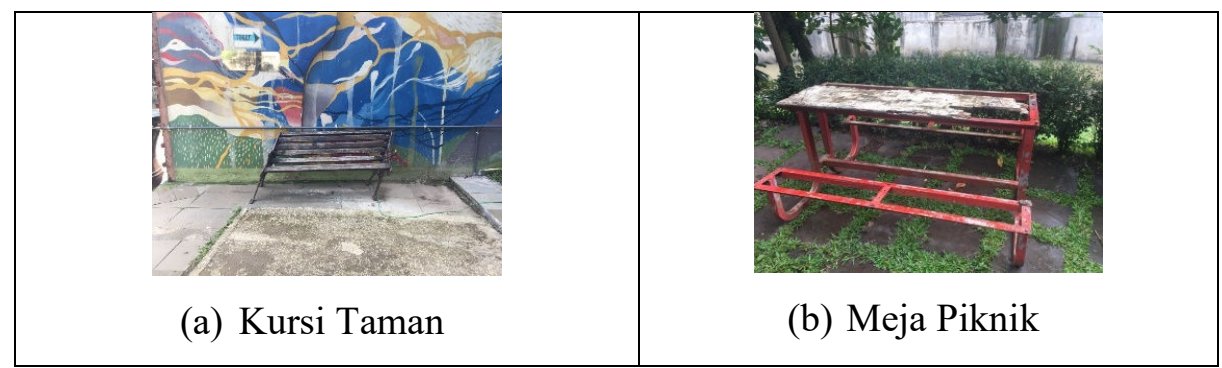

Gambar 3. Kondisi Kursi Taman dan Meja Piknik

Sumber : Penyusun, 2021

Berdasarkan uraian indikasi permasalahan yang telah dipaparkan terkait kinerja aset fasilitas rekreasi di Teras Cikapundung Kota Bandung, perlu dilakukan evaluasi dengan menganalisis permasalahan kinerja aset pada obek supaya dapat diolah dan memberikan rekomendasi yang tepat. Oleh karena itu, dilakukan studi kasus dengan judul "Evaluasi Kinerja Aset Fasilitas Rekreasi di Teras Cikapundung Kota Bandung" berdasarkan The Recreational Facility Audit Tool (RecFAT) menurut Macfarlane et al (2013).

\section{METODOLOGI}

Metode penelitian yang digunakan pada penelitian ini adalah penelitian deskriptif. Menurut Sugiama (2014) metode deskriptif adalah riset yang berupaya mengumpulkan data, menganalisis secara kritis atas data-data tersebut dan menyimpulkan berdasarkan fakta-fakta pada masa penelitian berlangsung atau masa sekarang. Metode deskriptif digunakan karena menjelaskan data yang ada di lapangan pada saat dilakukan penelitian. Pendekatan penelitian yang digunakan pada penelitian ini adalah penelitian kuantitatif. Penelitian kuantitatif adalah metode penelitian yang digunakan untuk meneliti populasi atau sampel tertentu dengan tujuan untuk menggambarkan dan menguji hipotesis (Sugiyono, 2017). Teknik pengumpulan data yang dilakukan adalah observasi, wawancara, dan studi dokumentasi.

Pada penelitian in evaluasi kinerja dilakukan untuk menentukan apakah kinerja aset sudah memenuhi tujuan awal dan sebagai tolak ukur untuk memperoleh kesimpulan dari hasil kinerja tersebut. Menurut Macfarlane et al (2013) terdapat sebuah alat yang dapat 
evaluasi karakteristik fasilitas rekreasi di ruang hijau perkotaan yaitu The Recreational Facility Audit Tool (RecFAT)) yang meliputi Availability of Sport Facilities, Accessibility, dan Availability of Supportive Amenities. Ada pun skema dapat dilihat pada gambar 4 berikut ini.

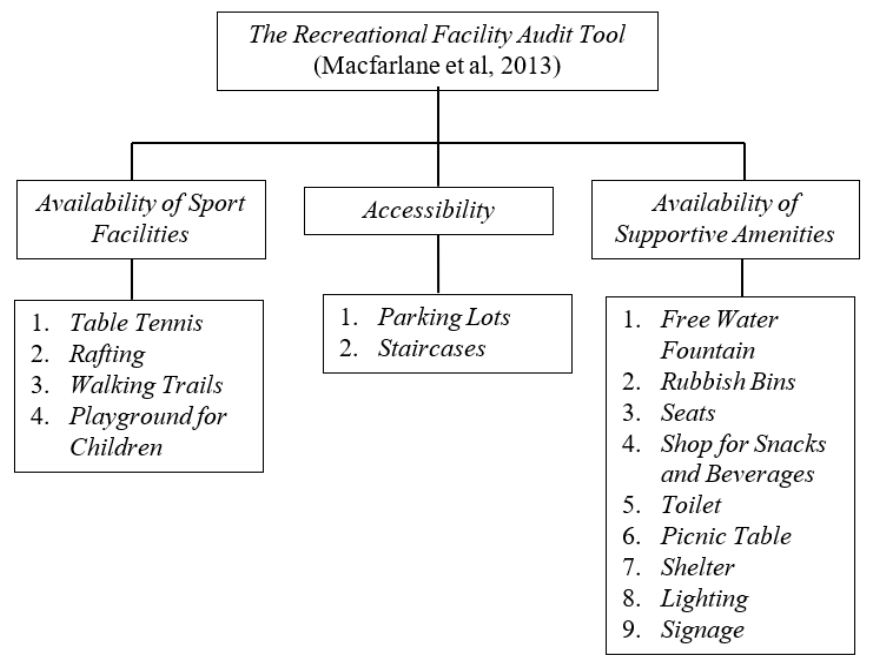

Gambar 4. Evaluasi Kinerja Fasilitas Rekreasi

Sumber : Modifikasi dari Macfarlane et al (2013)

\section{Availability of Sport Facilities}

Menurut Bell (2008) air merupakan elemen penting terutama dalam mendesain sebuah lansekap. Air yang mengalir memiliki atraksi tersendiri termasuk bantaran sungai dalam hal rekreasi dapat dijadikan sebagai wadah aktivitas fisik. Kategori aktivitas fisik yaitu mencakup aktivitas berjalan (jogging, hiking, bersepeda), aktivitas sosial (olahraga, piknik, berkemah), aktivitas artistik (melukis, fotografi), aktivitas petualangan (outbond), dan kegiatan survival (Arifin, 2011). Sarana dan prasarana olahraga merupakan sebuah benda yang bergerak maupun tidak bergerak yang diperlukan sebagai penunjang penyelenggaran kegiatan olahraga aktif dan pasif (Firdaus et al, 2015). Indikator yang digunakan pada dimensi availability of Sport Facilities menurut Macfarlane et al (2013) yaitu table tennis court, rafting, walking trails, dan playground for children.

\section{Accessibility}

Salah satu aspek penting dari suatu taman atau tempat rekreasi adalah aksesibilitas. Adanya aksesibilitas dapat memeriksa tingkat kemudahan di mana orang dapat mengakses fasilitas rekreasi (Macfarlane et al, 2013). Akses ke taman dapat ditentukan oleh tingkat dan kualitas rambu-rambu yang memberikan informasi kepada pengunjung, tanda-tanda ini 
dapat berupa bangunan, landmark, monumen, atau patung (Das dan Honiball, 2016). Menurut Macfarlane et al (2013) indikator aksesibilitas dapat diukur berdasarkan parking lots dan staircases.

\section{Availability of Supportive Amenties}

Amenities merupakan fasilitas dan layanan untuk wisatawan berkunjung di suatu destinasi ataupun objek wisata seperti menyediakan makan dan minum, hiburan dan pelayanan lainnya. Dimensi availability of supportive amenities mengevaluasi keberadaan sumber daya pelengkap yang mendukung penggunaan fasilitas selama kunjungan dari masyarakat. Indikator amenities dapat diukur berdasarkan ketersediaan free water fountains, rubbish bins, seats, shops for snacks or beverages, and toilets (Macfarlane et al, 2013), picnic table, shelter, dan lightning (Voigt et al, 2014) dan signage (Ngesan et al, 2013). Maka indikator yang digunakan untuk mengukur availability of supportive amenities adalah free water fountains, rubbish bins, seats, shops for snacks or beverages, toilets, picnic table, shelters, lighting, dan signage.

Adapun landasan normatif yang digunakan dalam penelitian ini adalah Peraturan Menteri Pekerjaan Umum Nomor 5 Tahun 2008 Tentang Penyediaan dan Pemanfaatan Ruang Terbuka Hijau Perkotaan, Peraturan Menteri Pariwisata Republik Indonesia Nomor 5 Tahun 2019 Tentang Petunjuk Operasional Pengelolaan Dana Alokasi Khusus Fisik Bidang Pariwisata, dan Peraturan Menteri Pekerjaan Umum Republik Indonesia Nomor: 168/KPTS/1998 tentang Persyaratan Teknis Aksesibilitas Pada Bangunan Umum dan Lingkungan.

\section{HASIL DAN PEMBAHASAN}

Evaluasi fasilitas rekreasi berdasarkan The Recreational Facility Audit Tool bertujuan untuk mengidentifikasi dan mendefinisikan masalah pada aset Teras Cikapundung Kota Bandung berdasarkan dimensi availability of sport facilities, accessibility, dan availability of supportive amenities (Macfarlane, 2013). Berikut ini merupakan hasil dan pembahasan evaluasi kinerja aset fasilitas rekreasi di Teras Cikapundung Kota Bandung.

\subsection{Evaluasi Dimensi Availability of Sport Facilities}

Availability of sport facilities adalah ketersediaan sarana olahraga yang ditinjau berdasarkan keberadaan lapangan dan perlengkapan olahraga di dalam sarana rekreasi (Macfarlane, 2013). Evaluasi dimensi availability of sport facilities pada Teras 
Cikapundung dilakukan menggunakan 3 indikator yaitu table tennis court, rafting, walking trails, dan playground for children. Berikut ini penjelasan hasil evaluasi pada masingmasing indikator availability of sport facilities dapat dilihat pada tabel 1.

Tabel 1. Hasil Evaluasi Dimensi Availability of Sport Facilities

\begin{tabular}{|c|c|c|c|c|}
\hline No & Indikator & Kriteria & Kondisi Eksisting & Hasil Evaluasi \\
\hline 1. & Table Tennis Court & $\begin{array}{l}\text { Ukuran lapangan tenis } \\
\text { meja yaitu panjang } \\
274 \mathrm{~cm} \text {, lebar } 152,5 \\
\mathrm{~cm} \text {, tinggi } 76 \mathrm{~cm} \text {, dan } \\
\text { tinggi net } 15,25 \mathrm{~cm}\end{array}$ & $\begin{array}{l}\text { Belum tersedia tenis } \\
\text { meja di Teras } \\
\text { Cikapundung }\end{array}$ & $\begin{array}{l}\text { Tidak sesuai } \\
\text { kriteria }\end{array}$ \\
\hline 2. & Rafting & $\begin{array}{l}\text { Ketersediaan wahana } \\
\text { seperti perahu karet, } \\
\text { kayak, kano, dan } \\
\text { dayung. Selain itu } \\
\text { terdapat peralatan } \\
\text { yang terdiri dari tali } \\
\text { lempar dan } \\
\text { perlengkapan P3K. }\end{array}$ & $\begin{array}{l}\text { Belum tersedia } \\
\text { perlengkapan P3K }\end{array}$ & $\begin{array}{l}\text { Tidak sesuai } \\
\text { kriteria }\end{array}$ \\
\hline \multirow[t]{2}{*}{3.} & \multirow[t]{2}{*}{ Walk Trails } & $\begin{array}{l}\text { Jalan setapak yang } \\
\text { dapat diakses oleh } \\
\text { penyandang disabilitas } \\
\text { memiliki lebar } 1,2 \mathrm{~m} \\
\text { atau } 1,5 \mathrm{~m} \text { dan bagi } \\
\text { pejalan kaki kurang } \\
\text { dari } 1,5 \mathrm{~m}\end{array}$ & $\begin{array}{l}\text { Jalur pejalan kaki } \\
\text { memiliki lebar } 1,5 \\
\text { m sehingga dapat } \\
\text { diakses oleh } \\
\text { penyandang } \\
\text { disabilitas dan } \\
\text { pejalan kaki biasa }\end{array}$ & Sesuai kriteria \\
\hline & & $\begin{array}{l}\text { Perkerasan jalur } \\
\text { pejalan kaki yaitu } \\
\text { harus anti slip, tidak } \\
\text { licin, serta rata dan } \\
\text { datar. }\end{array}$ & $\begin{array}{l}\text { Jalur pejalan kaki } \\
\text { apabila hujan } \\
\text { dipenuhi oleh tanah } \\
\text { sehingga licin }\end{array}$ & $\begin{array}{l}\text { Tidak sesuai } \\
\text { kriteria }\end{array}$ \\
\hline 4. & $\begin{array}{l}\text { Playground for } \\
\text { Children }\end{array}$ & $\begin{array}{l}\text { Permainan anak pada } \\
\text { tempat rekreasi harus } \\
\text { memiliki } 3 \text { tipe umum } \\
\text { permainan yaitu motor } \\
\text { play, social play, dan } \\
\text { cognitive play }\end{array}$ & $\begin{array}{l}\text { Permainan yang } \\
\text { disediakan di Teras } \\
\text { Cikapundung hanya } \\
\text { termasuk pada } \\
\text { motor play }\end{array}$ & $\begin{array}{l}\text { Tidak sesuai } \\
\text { kriteria }\end{array}$ \\
\hline
\end{tabular}

Berdasarkan hasil perbandingan antara kondisi eksisting dan kriteria, maka dimensi availability of sport facilities menunjukkan hasil kinerja yang kurang baik. Perlu dilakukan penambahan fasilitas olahraga berupa table tennis court. Pada indikator rafting perlu disediakan perlengkapan $\mathrm{P} 3 \mathrm{~K}$, pada indikator playground for children hanya terdapat 2 jenis permainan anak yang termasuk pada motor play. Maka dari itu perlu dilakukan penambahan aset fasilitas berupa table tennis court dan permainan anak, serta penambahan 
perlengkapan P3K. Selain itu pemeliharaan pada permainan anak yang sudah ada perlu dilakukan supaya permainan tersebut dapat dioperasikan dalam kondisi yang baik.

\subsection{Evaluasi Dimensi Accessibility}

Ruang publik yang sukses digambarkan sebagai tempat yang mudah diakses oleh semua individu seperti orang muda, orang lanjut usia, orang berkebutuhan khusus, pengguna kereta bayi dan pengendara sepeda (Gurer et al, 2017). Evaluasi dimensi accessibility pada Teras Cikapundung dilakukan menggunakan 2 indikator yaitu parking lots dan staircases. Berikut ini hasil evaluasi pada dimensi accessibility dapat dilihat pada tabel 2 .

Tabel 2. Evaluasi Dimensi Accessibility

\begin{tabular}{|c|l|l|l|l|}
\hline No & \multicolumn{1}{|c|}{ Indikator } & \multicolumn{1}{|c|}{ Kriteria } & Kondisi Eksisting & Hasil Evaluasi \\
\hline \multirow{4}{*}{1.} & \multirow{2}{*}{ Parking Lots } & $\begin{array}{l}\text { Tersedia tempat } \\
\text { parkir untuk } \\
\text { kendaraan roda } \\
\text { empat, dua, dan } \\
\text { sepeda }\end{array}$ & $\begin{array}{l}\text { Tidak tersedia } \\
\text { tempat parkir khusus } \\
\text { sepeda }\end{array}$ & $\begin{array}{l}\text { Tidak sesuai } \\
\text { kriteria }\end{array}$ \\
\cline { 3 - 5 } & $\begin{array}{l}\text { Penentuan satuan } \\
\text { ruang parkir }\end{array}$ & $\begin{array}{l}\text { Belum menerapkan } \\
\text { penentuan satuan } \\
\text { ruang parkir }\end{array}$ & $\begin{array}{l}\text { Tidak sesuai } \\
\text { kriteria }\end{array}$ \\
\hline \multirow{2}{*}{2.} & Staircases & $\begin{array}{l}\text { Tangga harus } \\
\text { memiliki dimensi } \\
\text { pijakan dan tanjakan } \\
\text { yang berukuran } \\
\text { seragam }\end{array}$ & $\begin{array}{l}\text { Dimensi pijakan dan } \\
\text { tanjakan tidak } \\
\text { seragam }\end{array}$ & $\begin{array}{l}\text { Tidak sesuai } \\
\text { kriteria }\end{array}$ \\
\cline { 3 - 5 } & $\begin{array}{l}\text { Tidak terdapat } \\
\text { tanjakan yang } \\
\text { berlubang }\end{array}$ & $\begin{array}{l}\text { Tidak ada tanjakan } \\
\text { yang berlubang }\end{array}$ & $\begin{array}{l}\text { Tidak sesuai } \\
\text { kriteria }\end{array}$ \\
\cline { 3 - 5 } & $\begin{array}{l}\text { Harus dilengkapi } \\
\text { dengan pegangan } \\
\text { minimum pada salah } \\
\text { satu sisi tangga }\end{array}$ & $\begin{array}{l}\text { Tangga tidak } \\
\text { dilengkapi oleh } \\
\text { pegangan }\end{array}$ & $\begin{array}{l}\text { Tidak sesuai } \\
\text { kriteria }\end{array}$ \\
\hline
\end{tabular}

Berdasarkan hasil evaluasi pada dimensi accessibility pada tabel 2 diketahui bahwa tempat parkir yang disediakan di Teras Cikapundung tidak memiliki tempat parkir khusus sepeda dan tidak menyediakan lahan parkir sesuai kebutuhan, selain itu pada indikator staircases dimensi pijakan dan tanjakan tidak seragam dan tangga tidak dilengkapi oleh pegangan sehingga dapat membahayakan pengunjung. Maka dimensi accessibility menunjukkan hasil kinerja yang kurang baik, sehingga perlu adanya penambahan aset fasilitas tempat parkir yang mencukupi, tempat parkir sepeda, dan tangga yang dilengkapi oleh pegangan. 


\subsection{Evaluasi Dimensi Availability of Supportive Amenities}

Fasilitas memainkan peran penting dalam membentuk kepuasan wisatawan (Dewi et al, 2017). Evaluasi dimensi availability of supportive amenities dilakukan menggunakan 9 indikator yaitu free water fountains, rubbish bins, seats, shops for snacks or beverages, toilets, picnic table, shelter, lightning, dan signage. Berikut ini hasil dari evaluasi dimensi availability of supportive amenities dapat dilihat pada tabel 3.

Tabel 3. Hasil Evaluasi Dimensi Availability of Supportive Amenities

\begin{tabular}{|c|c|c|c|c|}
\hline No. & Indikator & Kriteria & Kondisi Eksisting & Hasil Evaluasi \\
\hline \multirow{2}{*}{1.} & \multirow{2}{*}{$\begin{array}{l}\text { Free Water } \\
\text { Fountains }\end{array}$} & $\begin{array}{l}\text { Ditempatkan pada } \\
\text { ketinggian yang sesuai } \\
\text { supaya dapat digunakan } \\
\text { oleh anak kecil dan } \\
\text { penyandang disabilitas }\end{array}$ & \multirow{2}{*}{$\begin{array}{l}\text { Teras Cikapundung } \\
\text { belum memiliki free } \\
\text { water fountians }\end{array}$} & \multirow{2}{*}{$\begin{array}{l}\text { Tidak sesuai } \\
\text { kriteria }\end{array}$} \\
\hline & & $\begin{array}{l}\text { Dipasang di tiang kayu } \\
\text { sederhana namun tetap } \\
\text { elegan dan disediakan di } \\
\text { sekitar area tempat parkir } \\
\text { atau blok toilet }\end{array}$ & & \\
\hline \multirow[t]{2}{*}{2.} & \multirow[t]{2}{*}{ Rubbish Bins } & $\begin{array}{l}\text { Tempat sampah diletakan } \\
\text { pada jarak } 15-20 \text { meter, } \\
\text { mudah diangkut, dan } \\
\text { dibedakan berdasarkan } \\
\text { jenis sampahnya }\end{array}$ & $\begin{array}{l}\text { Tempat sampah yang } \\
\text { disediakan di Teras } \\
\text { Cikapundung hanya } \\
\text { berjumlah } 2 \text { dan tidak } \\
\text { dibedakan berdasarkan } \\
\text { jenisnya }\end{array}$ & \multirow[t]{2}{*}{$\begin{array}{l}\text { Tidak sesuai } \\
\text { kriteria }\end{array}$} \\
\hline & & $\begin{array}{l}\text { Tempat sampah memiliki } \\
\text { penutup }\end{array}$ & $\begin{array}{l}\text { Tidak terdapat penutup } \\
\text { pada tempat sampah }\end{array}$ & \\
\hline \multirow[b]{2}{*}{3.} & \multirow[b]{2}{*}{ Seats } & $\begin{array}{l}\text { Bangku ditempatkan di } \\
\text { tempat yang menarik dan } \\
\text { memiliki pemandangan } \\
\text { yang bagus }\end{array}$ & $\begin{array}{l}\text { Bangku tidak } \\
\text { ditempatkan di dekat } \\
\text { toilet dan tidak } \\
\text { memberikan } \\
\text { pemandangan yang } \\
\text { bagus }\end{array}$ & \multirow[b]{2}{*}{$\begin{array}{l}\text { Tidak sesuai } \\
\text { kriteria }\end{array}$} \\
\hline & & $\begin{array}{l}\text { Bangku ditempatkan di } \\
\text { tempat yang mudah } \\
\text { dijangkau serta dalam } \\
\text { kondisi terpelihara }\end{array}$ & $\begin{array}{l}\text { Bangku tidak dalam } \\
\text { kondisi baik karena } \\
\text { sudah lapuk, kayunya } \\
\text { sudah keropos, dan } \\
\text { kaki bangku tidak } \\
\text { dapat menyangga } \\
\text { sehingga bangku } \\
\text { berbentuk miring }\end{array}$ & \\
\hline \multirow[b]{2}{*}{4.} & \multirow{2}{*}{$\begin{array}{l}\text { Shops for } \\
\text { Snacks and } \\
\text { Beverages }\end{array}$} & $\begin{array}{l}\text { Tempat makan } \\
\text { menyediakan } 5 \text { jenis } \\
\text { kuliner }\end{array}$ & $\begin{array}{l}\text { Terdapat berbagai } \\
\text { jenis kuliner yang } \\
\text { disediakan di Teras } \\
\text { Cikapundung }\end{array}$ & \multirow{2}{*}{$\begin{array}{l}\text { Belum memenuhi } \\
\text { kriteria }\end{array}$} \\
\hline & & $\begin{array}{l}\text { Terdapat petunjuk } \\
\text { arah/papan nama dengan } \\
\text { tulisann yang terbaca } \\
\text { jelas dan mudah terlihat }\end{array}$ & $\begin{array}{l}\text { Tidak terdapat } \\
\text { petunjuk arah/papan } \\
\text { nama yang } \\
\text { menujukkan di mana } \\
\text { tempat makan berada }\end{array}$ & \\
\hline
\end{tabular}




\begin{tabular}{|c|c|c|c|c|}
\hline No. & Indikator & Kriteria & Kondisi Eksisting & Hasil Evaluasi \\
\hline \multirow{3}{*}{5.} & \multirow{3}{*}{ Toilet } & $\begin{array}{l}\text { Toilet harus dipisah } \\
\text { antara pria dan wanita }\end{array}$ & $\begin{array}{l}\text { Toilet tidak dipisahkan } \\
\text { antara pria dan wanita }\end{array}$ & \multirow{3}{*}{$\begin{array}{l}\text { Tidak sesuai } \\
\text { kriteria }\end{array}$} \\
\hline & & $\begin{array}{l}\text { Toilet harus dilengkapi } \\
\text { dengan peralatan yang } \\
\text { lengkap dan dalam } \\
\text { kondisi bersih }\end{array}$ & $\begin{array}{l}\text { Toilet tidak dilengkapi } \\
\text { oleh peralatan yang } \\
\text { lengkap dan dalam } \\
\text { kondisi kotor }\end{array}$ & \\
\hline & & $\begin{array}{l}\text { Terdapat standar ukuran } \\
\text { fasilitas pada toilet } \\
\text { berdasarkan Peraturan } \\
\text { Menteri Pariwisata } \\
\text { Nomor } 5 \text { Tahun } 2019 \\
\end{array}$ & $\begin{array}{l}\text { Toilet di Teras } \\
\text { Cikapundung belum } \\
\text { mengikuti standar } \\
\text { ukuran fasilitas pada } \\
\text { toilet }\end{array}$ & \\
\hline \multirow[b]{2}{*}{6.} & \multirow[b]{2}{*}{ Picnic Table } & $\begin{array}{l}\text { Meja piknik dirancang } \\
\text { supaya dapat digunakan } \\
\text { oleh siapa saja }\end{array}$ & $\begin{array}{l}\text { Meja piknik dapat } \\
\text { digunakan oleh siapa } \\
\text { saja }\end{array}$ & \multirow[b]{2}{*}{$\begin{array}{l}\text { Belum memenuhi } \\
\text { kriteria }\end{array}$} \\
\hline & & $\begin{array}{l}\text { Memberi layanan } \\
\text { tertinggi apabila semua } \\
\text { meja bersih dan memberi } \\
\text { layanan terendah apabila } \\
\text { meja piknik dalam } \\
\text { keadaan kotor dan rusak }\end{array}$ & $\begin{array}{l}4 \text { dari } 5 \text { meja piknik } \\
\text { dalam kondisi rusak } \\
\text { dan kotor }\end{array}$ & \\
\hline 7. & Shelter & $\begin{array}{l}\text { Ditempatkan di tempat } \\
\text { yang dapat memantau } \\
\text { permainan anak dan } \\
\text { menjadi tempat } \\
\text { berkumpul }\end{array}$ & $\begin{array}{l}\text { Shelter dalam kondisi } \\
\text { baik dan ditempatkan } \\
\text { di tempat strategis dan } \\
\text { dapat memantau } \\
\text { kegiatan anak-anak }\end{array}$ & Sesuai kriteria \\
\hline 8. & Lighting & $\begin{array}{l}\text { Jenis pencahayaan untuk } \\
\text { penerangan taman dan } \\
\text { area sekitarnya adalah } \\
\text { berwarna orange/jingga, } \\
\text { sedangkan di tempat } \\
\text { yang membutuhkan } \\
\text { tingkat keamanan lebih } \\
\text { tinggi menggunakan } \\
\text { lampu cahaya berwarna } \\
\text { putih }\end{array}$ & $\begin{array}{l}\text { Penerangan sudah } \\
\text { merata, warna lampu } \\
\text { yang digunakan sudah } \\
\text { sesuai dengan } \\
\text { kebutuhan setiap area } \\
\text { tetapi beberapa tiang } \\
\text { penerangan tidak } \\
\text { dilengkapi oleh lampu } \\
\text { dan wadah lampu } \\
\text { taman pecah }\end{array}$ & $\begin{array}{l}\text { Belum memenuhi } \\
\text { kriteria }\end{array}$ \\
\hline \multirow[b]{2}{*}{9.} & \multirow[b]{2}{*}{ Signage } & $\begin{array}{l}\text { Ketersediaan rambu } \\
\text { harus jelas dan dapat } \\
\text { terbaca oleh orang tua }\end{array}$ & $\begin{array}{l}\text { Rambu-rambu yang } \\
\text { disediakan sudah jelas } \\
\text { dan bisa terbaca oleh } \\
\text { orang tua }\end{array}$ & \multirow[b]{2}{*}{$\begin{array}{l}\text { Belum memenuhi } \\
\text { kriteria }\end{array}$} \\
\hline & & $\begin{array}{l}\text { Jenis rambu yang harus } \\
\text { disediakan adalah pre- } \\
\text { arrival, threshold, } \\
\text { orientation, direction, } \\
\text { identification, } \\
\text { information, } \\
\text { interpretation, regulation }\end{array}$ & $\begin{array}{l}\text { Jenis rambu yang } \\
\text { tersedia hanya ada } 2 \\
\text { jenis yaitu direction } \\
\text { dan information }\end{array}$ & \\
\hline
\end{tabular}

Berdasarkan hasil evaluasi dimensi availability of supportive amenities pada tabel 3 diketahui di Teras Cikapundung belum menyediakan free water fountains. Saat ini tempat sampah yang disediakan belum memenuhi kebutuhan karena hanya ditemukan 2 tempat 
sampah di sekitar Teras Cikapundung, selain itu tempat sampah yang ada tidak dibedakan jenisnya antara organik, anorganik, dan beracun, serta tidak ada penutup pada tempat sampah tersebut. Bangku yang disediakan berada dalam kondisi rusak berat dan ditempatkan di tempat yang tidak menarik yaitu di dekat toilet. Tempat makan yang ada menyediakan berbagai jenis makanan, tetapi tidak ditemukan petunjuk arah/papan nama yang menunjukkan letak tempat makan di Teras Cikapundung. Terdapat 2 toilet yang disediakan tetapi kedua toilet tersebut tidak dipisahkan antara pria dan wanita, selain itu juga toilet tidak dilengkapi oleh peralatan yang lengkap. Lalu ditemukan kondisi meja piknik dalam keadaan rusak berat. Pada penerangan warna lampu yang digunakan sudah sesuai dengan area taman, tetapi beberapa tiang penerangan tidak dilengkapi oleh lampu dan 6 wadah lampu taman ditemukan pecah. Ketersediaan rambu-rambu yang ada di Teras Cikapundung hanya terdapat 2 dari 8 jenis rambu yang harus disediakan yaitu direction dan information. Maka dari itu perlu dilakukan perawatan dan perbaikan aset fasilitas seperti bangku, toilet, meja piknik, dan penerangan. Selain perawatan dan perbaikan pada Teras Cikapundung perlu dilakukan penambahan aset fasilitas seperti free water fountains, tempat sampah, peralatan untuk toilet, dan rambu.

\section{KESIMPULAN DAN SARAN}

Dari hasil studi kasus evaluasi kinerja aset fasilitas rekreasi di Teras Cikapundung Kota Bandung, terdapat kesimpulan dari permasalahan tersebut serta saran-saran berdasarkan hasil evaluasi yang telah dilakukan. Berikut ini hasil kesimpulan dan saran.

\subsection{Kesimpulan}

Teras Cikapundung Kota Bandung dievaluasi berdasarkan The Recreational Facility Audit Tool meliputi availability of sport facilities, accessibility, dan availability of supportive amenities (Macfarlane et al, 2013). Definisi masalah pada aset fasilitas rekreasi Teras Cikapundung diuraikan sebagai berikut.

1. Kinerja aset fasilitas rekreasi di Teras Cikapundung berdasarkan availability of sport facilities belum menunjukkan hasil yang baik dikarenakan permasalahan sebagai berikut:

a. Belum tersedianya fasilitas olahraga yang lengkap seperti table tennis court. Selain itu pada fasilitas olahraga rafting belum disediakan perlengkapan keselamatan berupa perlengkapan P3K. 
b. Penggunaan material yang digunakan sebagai jalur pejalan kaki tidak anti slip dan licin.

c. Salah satu wahana permainan anak tidak beroperasi yaitu wahana kereta anak sedangkan wahana kora-kora masih dioperasikan tapi dalam kondisi tidak terawat karena wahana kotor dan berkarat.

2. Kinerja aset fasilitas rekreasi di Teras Cikapundung berdasarkan dimensi accessibility masih kurang baik dikarenakan permasalahan sebagai berikut:

a. Teras Cikapundung tidak menyediakan tempat parkir untuk sepeda dan tidak ada pembatas antara tempat parkir motor dan mobil.

b. Tangga yang ada tidak memiliki dimensi pijakan dan tanjakan yang seragam serta tidak dilengkapi oleh pegangan dan tidak dapat diakses oleh penyandang disabilitas.

3. Kinerja aset fasilitas rekreasi di Teras Cikapundung berdasarkan availability of supportive amenities masih kurang baik dikarenakan permasalahan sebagai berikut:

a. Teras Cikapundung belum memiliki free water fountains.

b. Tempat sampah yang disediakan hanya berjumlah 2 tidak dilengkapi oleh penutup dan tidak dibedakan berdasarkan jenisnya.

c. Bangku dan meja piknik dalam keadaan rusak berat.

d. Toilet yang disediakan kecil, tidak dibedakan berdasarkan jenis kelamin, dan tidak dilengkapi oleh peralatan yang lengkap. Selain itu belum tersedia toilet bagi pengunjung penyandang disabilitas.

e. Warna lampu sudah sesuai tetapi beberapa tiang lampu tidak dilengkapi oleh bohlam dan beberapa wadah lampu taman pecah.

f. Hanya terdapat 2 dari 8 jenis rambu yang seharusnya disediakan di Teras Cikapundung.

\subsection{Saran}

Berdasarkan definisi masalah yang telah diuraikan, maka saran yang dapat diajukan terkait evaluasi kinerja aset fasilitas rekreasi berdasarkan The Recreational Facility Audit Tool meliputi availability of sport facilities, accessibility, dan availability of supportive amenities pada Teras Cikapundung yaitu:

1. Availability of Sport Facilities

Perlu adanya penambahan fasilitas olahraga seperti table tennis court dan basketball court. Penggunaan bahan material yang aman untuk jalur pejalan kaki. Selain itu, 
perlu dilakukan perawatan pada aset permainan anak wahana kora-kora dan perbaikan pada permainan kereta anak supaya dapat digunakan kembali.

2. Accessibility

Perlu menyediakan tempat parkir sepeda dan rambu/pembatas parkir mobil dan motor. Selain itu dilakukan perbaikan pada dimensi pijakan tangga supaya seragam dan melengkapi tangga dengan pegangan.

\section{Availability of Supportive Amenities}

Perlu penambahan fasilitas seperti free water fountain, tempat sampah berdasarkan jenisnya, peralatan pelengkap di toilet, bohlam untuk penerangan taman, dan rambu. Selain itu perlu dilakukan perawatan dan perbaikan pada bangku, meja piknik, dan lampu.

\section{DAFTAR PUSTAKA}

Arifin, K. C. (2011). Perencanaan lanskap rekreasi di Bantaran Kanal Banjir Timur, Jakarta. Bogor, Indonesia: Departemen Arsitektur.

Atmojo, S.W. (2007). Menciptakan Taman Kota Berseri. Solo: Solo Pos.

Bell, S. (2008). Design for Outdoor Recreation. New York: Taylor\&Francis.

Das, D., \& Honiball, J. (2016). Evaluation of accessibility challenges of public parks in residential areas of South African cities-a case study of Bloemfontein City. 35th Annual Southern African Transport Conference.

Dewi, N. I. K., Astawa, I. P., Siwantara, I. W., and Bagus, I. G. A. 2017. Strategy Development: Case Study on Two Cultural Villages in Bali. Journal of Advances in Humanities and Social Sciences 3(6): 293-302.

Firdaus, M., \& Purnomo, A. M. I. (2015). Pemanfaatan Taman Rekreasi Selomangkleng (Klotok) Sebagai Sarana dan Prasarana Olahraga Masyarakat Di Kota Kediri. Jurnal SPORTIF : Jurnal Penelitian Pembelajaran, 1(1), 81-99.

Gürer, N., Güzel, B. I., \& Kavak, I. (2017). Evaluation on Living Public Spaces and Their Qualities - Case Study from Ankara Konur, Karanfil and Yüksel Streets. Materials Science and Engineering, 245, 072038.

Irwan, Z. D. (2007). Prinsip-Prinsip Ekologi: Ekosistem Lingkungan dan Pelestarian. Jakarta: Bumi Aksara.

Ives, C., Oke, C., Cooke, B., Gordon, A., \& Sarah, B. (2014). Planning for Green Open Space in Urbanising Landscapes.

Joga, N., \& Ismaun, I. (2011). RTH 30\%! Resolusi (Kota) Hijau. Jakarta: PT. Gramedia Pustaka Utama.

K. Y. Lee, D. Macfarlane, and E. Cerin. (2013). Objective evaluation of recreational facilities: development and reliability of the recreational facility audit tool. Journal of Park and Recreation Administration, vol. 31, no. 4, pp. 92-109.

Ngesan, M. R., Karim, H. A., \& Zubir, S. S. (2013). Image of Urban Public Park during Nighttime in Relation to Place Identity. Social and Behavioral Sciences 101, $328-$ 337. 
Samsudi. (2010). Ruang Terbuka Hijau Kebutuhan Tata Ruang Perkotaan Kota Surakarta. Rural and Development, 1(1).

Šiljeg, S., Marić, I., Nikolić , G., \& Šiljeg, A. (2018). Accessibility Analysis of Urban Green Spaces in The Settlement of Zadar in Croatia. 287-297.

Sugiama, A Gima. 2013. Manajemen Aset Pariwisata. Bandung : Guardaya Intimarta.

Sugiyono. 2017. Metode Penelitian Kuantitatif, Kualitatif, dan R\&D. Bandung : Alfabeta, CV.

Peraturan Menteri Pekerjaan Umum Nomor: 05/PRT/M/2008 tentang Pedoman Penyediaan dan Pemanfaatan Ruang Terbuka Hijau di Kawasan Perkotaan.

Peraturan Menteri Pariwisata Republik Indonesia Nomor 5 Tahun 2019 Tentang Petunjuk Operasional Pengelolaan Dana Alokasi Khusus Fisik Bidang Pariwisata.

Voigt, A., Kabisch, N., Wurster, D., Haase, D., \& Breuste, J. (2014). Structural Diversity: A Multi-dimensional Approach to Assess Recreational Services in Urban Parks. AMBIO, 43(4), 480-491. https://doi.org/10.1007/S13280-014-0508-9. 